\title{
Ideology in Indonesian language policies
}

\author{
Amirullah Abduh \\ Faculty of Language and Linguistic \\ Universitas Negeri Makassar \\ Makassar, Indonesia
}

\author{
Syukur Saud \\ Faculty of Language and Linguistic \\ Universitas Negeri Makassar \\ Makassar, Indonesia
}

\begin{abstract}
The objectives of this research were (1) to explore ideologies underpinning Indonesian language policy; and (2) to find out the features of ideological spaces of Indonesian language policy. The sample consisted of five important government regulations related to Indonesian language documents. The data on language ideology were analyzed through NVivo thematic approach. The findings of the research showed that there were five important ideologies underpinning language policies in Indonesian context: Indonesiasm, Globalism, Asianism, and Vernacularism. These ideologies were embedded in the policy that guides the practice. The implication is that the understanding of language ideology can impact on the practice of language policy at national and university levels in Indonesia.
\end{abstract}

\section{Keywords_Indonesian Language; Ideology; Policy}

\section{INTRODUCTION}

This article was undoubtedly necessary the underpinning ideologies which were the values and beliefs in the implementation of language policy. Language ideology has been the focus of the debates among scholars and researchers in language education. For example, R. Phillipson warned that the expansion of language ideology in most developed countries might be transformed in other non-developing countries, such as Indonesia[1]. Research on language ideology in Indonesia has been explored [2], [3].

The national language of the Republic of Indonesia is called Bahasa Indonesia. It unites over 254 million people whose native tongue consists of more than 300 distinct languages or regional dialects. Bahasa Indonesia is the language that unites the people of Indonesia. Since October 1928, Youth Pledge, in the third bullet "Kami poetra dan putri Inonesia berbahsa satu yaitu bahasa Indonesia." It can be translated as we are man and women of Indonesian use only one language which is Bahasa Indonesia proves that Indonesian is the official language for the Indonesian nation and we hope that we can uphold the Indonesian language.

However, P.H. Lowenberg and J. Hoffman research mainly focused on identity and had not stated clearly the features of ideology that underpinned Indonesian language policy[2], [3]. Thus, it evident that little information can be found on language ideology within Indonesian contexts. Therefore, this article addresses this gap and contribute to the better understanding of gender equality and its distribution in English language contexts globally and locally.
The current debates on the language ideology have brought some interpretations. Linguistics ideology is "sets of beliefs about language articulated by users as a rationalization or justification of perceived language structure and use." The ideology refers to neutral and critical values [4].

The ideology in language can be as an economically driven which is marked by the form of neo-liberalism. The neoliberalism' is defined as a specific ideological (economic) discourse which penetrates both the market as well as everyday lives [5]. The neo-liberalism ideology in language contexts is seen as 'linguistics imperialism' R. Phillipson particularly the expansion and the export of teaching materials, curriculum, and experts from UK and US across the globe[1].

The expansion of neo-liberalism language ideology has underpinned the language policy and education such as in Australia. J. Lo Bianco describes Australian language ideology as Britishism, Australianism, Multiculturalism, Asianism, and Economism[6]. These fives set of beliefs and principles are articulated in the early and current development of language policy and education in the Australian context.

In contrast, language and ideology are not truly connected to one in another since there is little evidence of the interrelation between language and neo-liberalism rather than language as discourse [7]. Holborow's insight does not take the view for granted that the English language itself constructs the hegemonic order of global capitalism[5].

\section{RESEARCH METHOD}

The data in this paper were taken five documents of Indonesian language policies. The first document is Law Number 24, 2009 on Flag, Languages, National Symbol, and National Anthem. The second document is Law Number 12, 2012 on Higher Education. The third document is Law Number 20, 2003 on National Education System. The fourth document is Government Regulation Number 57, 2014 on Development, Maintenance and Improvement of Indonesian language. The firth document is Ministry of Education and Culture Decree Number 50, 2015 on Guidance on Indonesian Language Rules. The data analyzed using N Vivo for helping users organizing and analyzing non-numerical data. The NVivo software consents to classify, sort and arrange information. The software also examines relationships in the data and combine analysis with connecting, determining, searching and modelling. Moreover, the researcher can test 
theories, and identify trends as well as cross-examine information in a multitude of ways using the search engine and query functions. Researchers can make observations in the software and build a body of evidence to support their research.

NVivo is one of the outstanding software that supports qualitative. It is designed to help organise, analyse and find insights in unstructured, or qualitative data like including interviews, articles, social media and web content. The process of data analysis via $\mathrm{N}$ Vivo [8] employs a cycling procedure which begins with importing pdf documents into NVivo. Then, the data are explored to identify the keywords from documents. Then the keywords are coded through the feature of the node. During these processes, a researcher can take note any additional comment or important idea appears through a memo.

\section{RESUlT AND DISCUSSION}

Language is a perfect communication tool than any other means or tools of communication. By using language, people can share information directly in their thoughts, ideas, intentions, feelings, and emotions. Bahasa Indonesia or Indonesia language as a communication tool has a significant role in unifying the diversity of regional languages in Indonesia because it can be unifying all the mother tongue language in one language that used in all area in Indonesia. Such diversity can be the treasure of the Nation's wealth. However, the Indonesian language as a unifying nation became the nation's ideology that should be a communication tool or communication practices of people of Indonesia.

Indonesian is a derivative language of Malay. The Malay language began to be worn in Southeast Asia since the 7th century. The evidence is that with the discovery of several inscriptions in Kedukan Bukit numerals in $683 \mathrm{M}$ (Palembang), Talang Tuwo numerals $684 \mathrm{M}$ (Palembang), Kapur City numerals 686 M (West Bangka), and Karang Brahi numerals $688 \mathrm{M}$ (Jambi ).

During the reign of Sriwijaya, the Malay language was often used to carry out trade and communicate among ethnic groups in the Malay archipelago. Apart from the fact that Bahasa Melayu became the language used for interpersonal communication, trade and other social activities, the dissemination of Bahasa Melayu was also similar to the spread of Islam so that the Indonesian people more easily accept Bahasa Malays. Then, Malay is used as a cultural language, which is the language of the Buddhist textbook.

The growing Malay language in Indonesia is an Austronesian language from the Sundanese-Sulawesi branch, used as Lingua Franca (Introduction) in the archipelago since the beginning of modern dating.

There are three ideologies other than vernacularization, namely linguistic assimilation, linguistic pluralism, and internationalism. Linguistic assimilation places the dominant language as the official language. All people or citizens or natives or migrants in Indonesia should learn and use the Indonesian language as the part not only transformed the information but also as the ideology of the Indonesia as one of the Nations in the world.

In applying J. Lo Bianco concept of ideologies, the ideological stances underpinning the development of language policy within Indonesian contexts can be described as follows[6]:

- Globalism: This is marked the emphasis on English rules about the internalisation of educational institutions particularly higher education as stated in the government policy documents. This links to the policy of attracting international students and produce graduates that qualify for the global labours and market.

- Asianism: This is marked by the insertion of the teaching foreign languages which mostly from Asian languages: Japanese, Mandarin, and Arabic. These national policies are tied with long historical and political relations with those Japanese, Chinese and Arab communities. The Arabic is the language of the Holy Qur'an, as Indonesia is the most populous Muslim nation; the Mandarin and Japanese have robust trade and market with Indonesia.

- Indonesiasm: This is marked by literary and sociopolitical affirmation of Bahasa Indonesia as a marker of national language and identity; this Indonesianism unifies multicultural and multi-ethnic representation as a symbol of a nation "Bhinneka Tunggal Ika" (we are different, but we are one). Also, the essential roles of Bahasa Indonesia in many various aspects of government and community events.

- The vernacularism is marked by the increasing interests of the number of higher education institutions established schools of local languages. In the two universities that I investigated, both of them have the schools of local languages. These schools are to prepare universities graduates to be able to teach in primary and secondary education.

With regard to the Indonesian language as a unifying nation because the Indonesian language is used as a means of communication among members of different ethnic groups. This is because it is impossible communication can be done in one of the regional languages of the tribe members. Communication is more likely to be done in the Indonesian language; it will create a feeling of "one nation" among members of the tribes.

Bahasa Indonesia is also the language of instruction in every kind of school as well as the language of liaison between each people of Indonesia with others, so it has a real social function. Bahasa Indonesia is the only language of Indonesian culture in the widest and deepest sense so that every opinion can be formulated and every feeling can be described in that language. Obviously we can see that the Indonesian language, not only as an official language in the Republic of Indonesia, but also as a language of unity, connecting language, social language and language of instruction in schools from Kindergarten to Higher Education. 
Bahasa Indonesia apart from unity in the ideals and spirit of struggle, can also be used as a unifying tool to express feelings, thoughts and wills.

As a unifying language, the Indonesian language into a national language is also enriched by various elements derived from regional and foreign languages. Indonesian nation consisting of hundreds of tribes that each has its own territory. For most Indonesian men's castles, the local language is the mother tongue for the community. The regional language is the language first learned, and then the Indonesian language is the second language learned in school and in the community.

Regional languages have enriched the Indonesian language, especially regarding his vocabulary. Not a few local languages are picked up and then become an Indonesian word. For example established, gembeleng (Javanese). Therefore, do not be surprised if the regional language is ingrained in the wearer and great influence for the mastery of the second language learned later is the Indonesian language.

\section{CONCLUSION}

The analysis illustrates how ideological spaces are created. The ideological stances are certainly in every establishment of language policy [9]. Particularly in the Indonesian language policy documents. The policy study suggests that there is a need to have a more comprehensive set of policy that can become an 'umbrella' of the higher education institutions. The overarching framework will help the flexibility and the direction of the future views of Indonesian language policy.

\section{REFERENCES}

[1] R. Phillipson, "The linguistic imperialism of neoliberal empire 1," Crit. Inq. Lang. Stud., vol. 5, no. 1, pp. 1-43, 2008.

[2] P. H. Lowenberg, "Language Policy and Language Identity in Indonesia.," J. Asian Pacific Commun., vol. 3, no. 1, pp. 59-77, 1992.

[3] J. Hoffman, “A foreign investment: Indies Malay to 1901," Indonesia, no. 27, pp. 65-92, 1979.

[4] K. A. Woolard and B. B. Schieffelin, "Language ideology," Annu. Rev. Anthropol., vol. 23, no. 1, pp. 55-82, 1994.

[5] R. Wodak, "Editorial: Language and Ideology-Language in Ideology.," J. Lang. Polit., vol. 6, no. 1, pp. 1-5, 2007.

[6] J. Lo Bianco, "Some ideas about multilingualism and national identity," TESOL Context, vol. 20, no. 1, p. 22, 2010.

[7] M. Holborow, "Language, ideology, and neoliberalism," J. Lang. Polit., vol. 6, no. 1, pp. 51-73, 2007.

[8] P. Bazeley and K. Jackson, Qualitative data analysis with NVivo. Sage Publications Limited, 2013.

[9] N. H. Hornberger and S. McKay, Sociolinguistics and language education, vol. 18. Multilingual Matters, 2010. 